\title{
Hvorfor ikke helseuniversiteter?
}

Spørsmålet om vi bør etablere helseuniversiteter i Norge har fătt økt aktualitet. Helseuniversiteter hvor medisinske fakulteter og helsefaglige utdanninger er organisatorisk slått sammen med universitetssykehus, finnes i flere land (Charité i Berlin, Johns Hopkins i Baltimore, flere i Nederland). En slik restrukturering av medisinsk og helsefaglig utdanning, forskning og klinisk virksomhet kan imidlertid få uheldige konsekvenser (1).

Ved alle våre medisinske fakulteter er nå de basalmedisinske instituttene etablert innenfor eller tett ved universitetssykehusene. Fra å være en av universitetets opprinnelige kjerneaktiviteter sammen med teologi og jus har fakultetsinstituttene bokstavelig talt «flyktet» fra campus. Samtidig har det skjedd en sterk profesjonsorientering av undervisningen. Den nye studieplanen i Oslo (Oslo96) vektlegger praktisk klinisk undervisning, kommunikasjon og utplassering både i sykehus og i allmennpraksis. Det er blitt langt færre forelesninger, og problembasert læring er innført. Tanken er at studentene bedre skal beherske den praktiske utøvelsen av yrket etter avlagt embetseksamen. Parallelt er også faget avakademisert på en annen måte. Antall leger har økt kraftig, men det er ikke blitt flere legeutdannede forskere (2). Dette er en internasjonal utvikling som har vakt betydelig bekymring, men som kanskje er i ferd med å snu (3).

Både i spesialisthelsetjenesteloven (§ 3-8) og i helseforetaksloven (§ 1-2) står forskning og utdanning eksplisitt nevnt som hovedoppgaver - selvfølgelig i tillegg til pasientbehandling. I så måte er disse lovene ganske lik universitets- og høyskoleloven. Derfor har Helseog omsorgsdepartementet øremerket forskningsmidler (445 mill. kr totalt i 2009) som deles ut av samarbeidsorganene i hver helseregion. I tillegg brukes det minst $1 \mathrm{mrd}$. $\mathrm{kr}$ av helsebudsjettet til forskning, primært ved universitetssykehusene (4). En slik satsing særlig på klinisk forskning i regi av helseforetakene har et dobbelt siktemål: kunnskapsbasert praksis og mer kompetanse i miljøene. De er styrket som forsknings- og utdanningsinstitusjoner.

Det har vært en kraftig økning av studenter på doktorgradsprogrammet. I Oslo er det flere enn 1000 - nesten like mange som på profesjonsstudiet. Omtrent halvparten av disse er leger. Mange doktorgradsstudenter er betalt gjennom helseforetakene. Universitetssykehusene betaler også for en rekke professor II-stillinger, holder kontorer og laboratorier og krever en stor andel av opphavsretten til oppfinnelser. Ambisjonene til helseforetakene er store. Helse Sør-Øst ønsker å bygge opp sin satsing på forskning til $5 \%$ av budsjettet, som i dag er på ca. 50 mrd. kr. Fakultetene er små i forhold til de ressursene universitetssykehusene rår over. Det kan synes som en praktisk formalitet å innlemme dem i foretaksstrukturen, men vil det være fornuftig og vil det demme opp for avakademiseringen?

For å svare på dette må man vurdere både hva universitetet kan by på og hvor medisinen beveger seg som fag. Universitetene har vært gjennom reformer og har ikke vært budsjettvinnere i kampen om ressursene til høyere utdanning og forskning. De medisinske fakultetene sliter med svært trange budsjetter. Noen klager over at universitetene er i ferd med å bli serviceinstitusjoner (5). Heldigvis er det sterke krefter som demmer opp for en slik utvikling. Vi har fått lovfestet retten til akademisk frihet (universitets- og høyskoleloven $\S 1-5)$, og det er tatt initiativ til å bevare universitetene som dannel- sesinstitusjoner (6). Det er også tatt viktige initiativer for å etablere tverrfakultære samarbeidskonstellasjoner.

Legeforeningen har publisert dokumentet «Mot en ny vår for medisinsk forskning» der man analyserer fagets utvikling og bl.a. peker på alle de viktige elementene som $i k k e$ hører hjemme i spesialisthelsetjenesten (7). For kommunehelsetjenesten er allmenn- og samfunnsmedisin og forebyggende medisin viktig, men det er også andre fag som atferdsfag, helsefag, helseledelse, helseøkonomi, medisinsk historie, etikk osv. som kanskje ville «drukne» innenfor rammen av et helseforetak. Det er grunn til å spørre om en del av den medisinske forskningen og fagutviklingen må ha et annet kunnskapsteoretisk grunnlag enn den tradisjonelle reduksjonistiske og hypotetisk-deduktive tilnærmingen. Utfordringene står også i kø utenfor sykehusene hvor praksis må være kunnskapsbasert f.eks. nettopp i allmenn- og samfunnsmedisinen. Utover det har vi et moralsk ansvar for å bidra etter evne til å løse de globale helseproblemene. Vi kommer til å møte stadig større etiske utfordringer når det gjelder våre oppfatninger om og håndtering av liv og død. Det er derfor viktig at studentene får med seg en god ballast. Den kan de best hente i universitetssamfunnet hvor dannelsesaspektet er vektlagt. Et slikt bredere perspektiv er i tråd med intensjonene i samhandlingsreformen (8).

De medisinske fakultetene bør profilere sin egenart som uavhengige og kritiske utdannings- og forskningsinstitusjoner innen rammen av et tradisjonelt og mangefasettert universitet og ikke la seg kjøpe billig av våre universitetssykehus. De må utvikle samarbeidet med de andre fakultetene og høyskolene og påvirke utviklingen av faget både innenfor og utenfor helseforetakene. Fakultetene må ha spissforskning og mangfold som favner hele bredden i faget. Mangfoldet og den kritiske sans kan lett gå tapt hvis vi samler for mye under en paraply i ett eller flere helseuniversiteter.

\section{Ole M. Sejersted}

o.m.sejersted@medisin.uio.no

Ole M. Sejersted (f. 1947) er professor i medisin og leder av Institutt for eksperimentell medisinsk forskning, Oslo universitetssykehus, Ullevål.

Oppgitte interessekonflikter: Ingen

\section{Litteratur}

1. Sejersted OM. Trenger vi et helseuniversitet i Norge? Nytt Norsk Tidsskrift 2009; 26: $97-110$.

2. Nes $M$, Røttingen JA. Leger og forskning - når er bunnen nådd? Tidsskr Nor Lægeforen 2003; 123: 344-5.

3. Sheridan DJ. Reversing the decline of academic medicine in Europe. Lancet 2006; 367: 1698-701.

4. Wiig 0. Ressursbruk til forskning i helseforetakene i 2006. Dokumentasjon av undersøkelsen og hovedresultater. Rapport 39/2007. Oslo: Stiftelsen Norsk institutt for studier av innovasjon, forskning og utdanning (NIFU STEP), 2007. 5. Eriksen TB. Hva skal vi egentlig med et universitet? Morgenbladet 3.10.2008 6. Hagtvet B, Bostad I, Dørum OE. Hva bør studenter lære i dag? Aftenposten 27.1.2009

7. Mot en ny vår for medisinsk forskning? Den norske legeforenings forskningspolitiske strategidokument 2008-2012. Notat fra Legeforeningens forskningsutvalg, avgitt til sentralstyret 31.1. 2007. www.legeforeningen.no/id/136156.0. (4.8.2009).

8. St.meld. nr. 47 (2008-2009). Samhandlingsreformen. Rett behandling - på rett sted - til rett tid. 